\title{
Change in phytoestrogen contents and antioxidant activity during fermentation of Cheonggukjang with bitter melon
}

\author{
Kye-Man Cho, Ok-Soo Joo* \\ Department of Food Science, Gyeongnam National University of Science and Technology, Jinju 660-758, Korea
}

\section{여주 첨가 청국장 발효 중 phytoestrogen 함량 및 항산화 활성 변화}

\author{
조계만 · 주옥수* \\ 경남과학기술대학교 식품과학부
}

\begin{abstract}
In this study, the $\beta$-glucosidase activity and total phenolic and isoflavone contents and antioxidant activities during Cheonggukjang fermentation with bitter melon powder (BMP) were investigated and evaluation of the same was performed. The level of $\beta$-glucosidase activity was increased at $48 \mathrm{hr}$ and decreased after $72 \mathrm{hr}$, and the total phenolic and isoflavone-malonylglycoside and aglycone contents increased, while the antioxidant activities increased, but the total isoflavone and isoflavone-glycoside contents decreased during the Cheonggukjang fermentation. In particular, the soybean with $5 \%$ BMP fermented at $37^{\circ} \mathrm{C}$ for $72 \mathrm{hr}$ displayed the highest antioxidant activities, among all the samples. The highest levels of total phenolic and daidzein contents and DPPH radical scavenging activity, ABTS radical scavenging activity and FRAP assay results after $\mathbf{7 2} \mathbf{~ h r}$ fermentation in Cheonggukjang with $5 \%$ BMP were found to be $13.5 \mathrm{mg} / \mathrm{g}, 390.57 \mathrm{\mu g} / \mathrm{g}, 90.74 \%, 99.79 \%$, and 1.705 (OD593 $\mathrm{nm}$ ) respectively. In addition, the more BMP was added to the Cheoggukjang, the more the off-odor of the Cheonggukjang decreased. These results suggest that BMP can be used to come up with a new type of Cheonggukjang with improved palatability and antioxidant activity.
\end{abstract}

Key words : bitter melon, Cheonggukjang, phenolics, isoflavone, antioxidant

\section{서 론}

콩(soybean, Glycine max L. Miller)은 우리 민족의 전통적 인 식품 원료로서 오래전부터 식물성 단백질 급원으로 아주 중요한 위치를 차지하고 있다. 콩에는 단백질뿐만 아니라 지방, 탄수화물, 무기질 및 식이섬유 등의 영양성분이 풍부 하고 인체의 건강 증진을 위한 생리활성 물질인 인지질, isoflavone, phenolic acids, saponins 및 phytic acid 등의 성분 이 함유되어 있다 $(1,2)$. 특히 isoflavone은 콩에 함유된 물질 중 가장 대표적인 기능성 화합물로 여성 호르몬인 estrogen

*Corresponding author. E-mail : osjoo@gntech.ac.kr Phone : 82-55-751-3273, Fax : 82-55-751-3279

Received 13 January 2015; Revised 4 February 2015; Accepted 5 February 2015.

Copyright (c) The Korean Society of Food Preservation. All rights reserved.
과 그 구조가 매우 흡사하여 phytoestrogen이라고 불리며 화학적 구조로 glycosides(24 25\%), malonylglycosides(70 $80 \%$ ), acetyl-glycosides(3 5\%) 및 aglycones(1 2\%) 형태 로 존재한다(3).

청국장은 증자 콩에 고초균(Bacillus subtilis)을 번식시켜 만든 전통발효식품으로 2 3일에 완성할 수 있으면서도 그 풍미가 독특하고 영양적, 경제적으로도 가장 효과적인 콩의 섭취방법으로 인정되고 있다(4). 특히 청국장은 된장 이나 고추장에 비해 단백질, 필수아미노산, 비타민 $\mathrm{B}_{1}, \mathrm{~B}_{2}$ 및 나이아신 등의 함량이 높으며 콩에서 기인하는 생리활성 물질과 항산화 물질이 다량 함유되어 있어 콜레스테롤 저 하, 항고혈압, 항암, 항산화 및 혈전용해 활성 등의 다양한 생리활성의 연구가 진행되어 보고되어 있다(5). 한편 청국 장의 기능성 및 품질 향상을 위해 홍삼, 당귀와 지황(6), 더덕(7), 배추(8), 마늘(2), 흑마늘(9), 녹차(4), 칡(10), 율무 (11) 및 작두콩(12) 등을 이용한 청국장의 제조와 이들의 
기능성에 대한 연구가 보고되어 있다.

여주(Momordica charantia L.)는 1년생 박과식물로 여자 또는 미숙 과실의 쓴맛 때문에 쓴오이(bitter gourd, bitter melon, bitter cucumber, bitter squash)라고 불리며 아마존, 동아프리카, 남아메리카, 카리브 지역, 아시아에서 재배되 고 있다(13). 특히 여주는 triterpenoids, polypeptides, saponins, alkaloids, 비타민 $\mathrm{C}$, 비타민 $\mathrm{K}, \mathrm{Ca}$ 과 $\mathrm{Mg}$ 등의 미네랄 및 $\beta$-carotene 등 여러 가지 생리활성물질들과 항산 화 성분을 함유 하고 있으며, 이외에도 활성성분으로 catechin 등의 flavan-3-ol 유도체와 protocatechuic acid 등의 phenolic acids가 보고되어 있으며, 항산화, 항암, 항괴사, 항고혈당, 항돌연변이, 항균작용 등과 같은 여러 가지의 효능이 보고되고 있다(14-17). 한편 여주는 국내·외에서 분 말제, 환, 주스 및 차 형태로 가공하여 이용하고 있어(18) 국내에서 생산량이 점점 더 증가하고 있는 여주의 활용성 증대를 위한 다양한 가공방법이 필요한 시점이다.

따라서 본 연구에서는 여주의 활용성 증대뿐만 아니라 청국장의 항산화 활성과 기호성 개선의 목적으로 여주를 이용한 청국장을 제조하고 발효 특성, isoflavone 함량 및 항산화 활성의 변화를 검토하였다.

\section{재료 및 방법}

재료, 발효 균주, 배지 및 시약

여주 분말은 경상남도 함양군 안의면 소재 함양영농조합 법인에서 2013년 7 8월에서 수확되어 건조하여 분말 제조 한 것을 공급받아 사용하였으며, 콩은 2012년 경상남도 밀 양시 농촌진흥청 국립식량과학원 기능성작물부에서 재배 및 수확된 대원콩을 공급받아 사용하였다. 발효 균주는 경 남과학기술대학교 식품미생물·위생실험실에서 이전에 분 리하여 보관하고 있던 Bacillus subtilis CSY191 균주를 사용 하였다(19). 고초균 배양배지로는 Tyrptic soy(TS, Difco, Becton Dicnson Co., MD, USA)를 사용하였다. $2 \mathrm{~N}$ Folin-Cialteu phenol reagent, 2,2-diphenyl-1-picrydrazyl (DPPH), 2,4,6-azinobis(3-ethyl-benzothiazoline-6-sulfonic acid) (ABTS), 2,4,6-tripyridyl-s-triazine(TPTZ) 및 glacial acetic acid는 Sigma-Aldrich(Saint Louis, MO, USA)에서 제품을 구입하여 사용하였다. 12 종류의 isoflavone 중 aglycones (daidzein, glycitein genistein)는 Sigma-Aldrich에서 구입하 였고 glycosides(daidzin, glycitin genistin)는 Indofine (Hillsborough, NJ, USA)에서 구입하였으며 malonylglycosides 및 acetylglycosides(malonyldaidzin, malonylglycitin, malonylgenistin, acetyldaidzin, acetylglycitin, 및 acetylgenistein) 는 LC Laboratories(Woburn, MA, USA)에서 구입하였다. Methanol, acetonitrile 및 water는 J.T.Baker(Philipsbug, NJ, USA)에서 구입하여 사용하였고 그 외 나머지 기타 시약은
특급 혹은 1 급을 필요에 따라 구매하여 사용하였다.

\section{청국장 제조 및 발효}

정선된 콩을 흐르는 물에 3회 수세하여 상온에서 12시간 동안 침지시킨 후 약 30 분간 물 빼기를 하고 stainless 발효용 기 $(30 \mathrm{~cm} \times 30 \mathrm{~cm} \times 10 \mathrm{~cm})$ 에 수침콩 $1,000 \mathrm{~g}$ 과 여주 분말을 $0 \%, 1.0 \%(10 \mathrm{~g}, \mathrm{w} / \mathrm{w}), 2.5 \%(25 \mathrm{~g}, \mathrm{w} / \mathrm{w})$ 및 $5.0 \%(50 \mathrm{~g}, \mathrm{w} / \mathrm{w})$ 담아 고압증기멸균기로 $121^{\circ} \mathrm{C}$ 에서 30 분간 증자하였다. 증 자한 콩을 $40^{\circ} \mathrm{C}$ 로 냉각시킨 후 $\mathrm{TS}$ 액체배지에 48 시간 배양 한 B. subtilis CSY191 균주를 $2.5 \%(\mathrm{v} / \mathrm{w})$ 접종하여 $37 \pm 2^{\circ} \mathrm{C}$ 의 배양기에서 72 시간 발효시켜 청국장을 제조하였고 0,12 , 24,48 및 72시간에 시료를 채취하였다.

\section{생균수 및 $\beta$-glucosidase 활성}

청국장 $10 \mathrm{~g}$ 을 멸균증류수 $90 \mathrm{~mL}$ 에 희석한 후 단계별로 희석하여 TS 평판배지에 도말하여 $37^{\circ} \mathrm{C}$ 에서 $48 \mathrm{hr}$ 배양 후 나타난 집락수를 계수하였다. 각 실험은 3회 반복하여 수행하여 평균값으로 나타내었으며 시료 $\mathrm{mL}$ 당 $\log$ colony forming unit $(\log \mathrm{CFU} / \mathrm{mL})$ 로 표시하였다.

발효 중 $\beta$-glucosidase 활성 측정은 Cho 등(20)의 방법에 준하여 측정하였다. 청국장 $10 \mathrm{~g}$ 에 $50 \mathrm{mM}$ sodium phosphate buffer(pH 7.0) $100 \mathrm{~mL}$ 과 혼합하고 $4^{\circ} \mathrm{C}$ 에서 $6,000 \times \mathrm{g}$ 로 30 $\mathrm{min}$ 동안 원심 분리한 후 상등액을 분석 전에 $0.45 \mu \mathrm{m}$ 필터 여과하여 조효소를 제조하였다. B-glucosidase 활성은 $\mathrm{p}-\mathrm{NPG}$ 의 가수분해율을 결정하여 분석하였다. 조효소 250 $\mu \mathrm{L}$ 은 $50 \mathrm{mM}$ sodium phosphate buffer(pH 7.0)에 $5 \mathrm{mM}$ $\mathrm{p}-\mathrm{NPG}$ 의 $250 \mu \mathrm{L}$ 를 가하였다. $37^{\circ} \mathrm{C}$ 에서 30 분 반응시킨 후 $500 \mu \mathrm{L}$ 의 $0.2 \mathrm{M}$ glycine- $\mathrm{NaOH}(\mathrm{pH}$ 10.5)를 가하여 효소 반응 을 멈추고 방출된 p-nitrophenol의 양은 $405 \mathrm{~nm}$ 에서 흡광도 를 측정하여 결정하였다. $\beta$-glucosidase의 1 unit은 $\mathrm{p}-\mathrm{NPG}$ 의 $1 \mu \mathrm{M}$ 을 유리하는 효소 양으로 정의하였다.

\section{추출물 제조}

시료추출물은 Cho 등(20)의 방법에 준하여 추출하였다. 동결건조 청국장 분말 $1 \mathrm{~g}$ 에 10 배의 $50 \%$ 메탄올을 가하고 상온에서 $160 \mathrm{rpm}$ 속도로 12 시간 추출하였다. 추출물은 원 심분리 후 $0.45 \mu \mathrm{m}$ membrane filter(Dismic-25CS, Toyoroshikaisha Ltd., Tokyo, Japan)로 여과하여 총 phenolics 와 isoflavone 함량 및 항산화 활성 측정을 위한 시료로 사용 하였다.

\section{Isoflavone 함량}

Isoflavone 함량 분석은 Cho 등(20)의 방법에 준하여 high performance liquid chromatography(HPLC, Agilent 1200 series, Agilent Co., Forest City, CA, USA)로 분석하였고 분석 column은 Lichrophore $100 \mathrm{RP}$ C18 column $(4.6 \times 250$ $\mathrm{mm}, 5 \mu \mathrm{m}$, Merck, Germany)을 사용하였다. 이동상 용매는 
$0.1 \%$ glacial acetic acid(solution A)와 $100 \%$ acetonitrile (solution B)로 분석하였고, 이동상 조건은 solvent $\mathrm{B}$ 기준으 로 각각 $20,10,10$ 및 $10 \mathrm{~min}$ 동안 $10 \%, 20 \%, 25 \%$ 및 $35 \%$ 로 유지시켰다. 시료는 $20 \mu \mathrm{L}$ 를 주입하였고 이동상의 속도는 $30^{\circ} \mathrm{C}$ 에서 $1 \mathrm{~mL} / \mathrm{min}$ 로 유지하였다. Isoflavone은 diode array UV detector(Agilent1200 series, Agilent Co., Forest City, CA, USA)의 흡광도 $254 \mathrm{~nm}$ 에서 정량하였다.

\section{총 phenolics}

청국장의 발효기간 중 총 phenolics 변화는 Folin-Denis법 (21)을 변형하여 측정하였다. 추출물을 적당히 희석한 후 희석액 $0.5 \mathrm{~mL}$ 를 시험관에 분주한 다음 $25 \% \mathrm{Na}_{2} \mathrm{CO}_{3}$ 용액 $0.5 \mathrm{~mL}$ 을 첨가하여 3 분간 정치시켰다. 다시 $2 \mathrm{~N}$ Folin-Ciocalteu phenol 시약 $0.25 \mathrm{~mL}$ 첨가하여 혼합한 다음 상온에서 1 시간 동안 정치시켜 발색시켰다. 발색된 청색을 분광광도계(Spectronic 2D, USA)를 이용하여 $750 \mathrm{~nm}$ 에서 흡광도를 측정하였다. 이때 수용성 phenolics 함량은 gallic $\mathrm{acid}$ 를 이용하여 작성한 표준곡선으로부터 함량을 구하였 다. 각 실험은 3회 반복하여 수행하여 평균값으로 나타냈었 다.

\section{$\mathrm{DPPH}$ 라디칼 소거 활성}

$\mathrm{DPPH}$ 라디칼 소거활성은 적당히 희석한 추출물 $0.2 \mathrm{~mL}$ 에 $1.5 \times 10^{-4} \mathrm{M} \mathrm{DPPH}$ 에탄올 용액 $0.8 \mathrm{~mL}$ 를 가하고 10 초간 vortex하여 혼합한 다음 실온에서 30 분간 방치한 후 525 $\mathrm{nm}$ 에서 흡광도를 측정하였다(5). 음성 대조구 실험은 시료 대신에 증류수를 $0.2 \mathrm{~mL}$ 를 취하여 사용하였다. $\mathrm{DPPH}$ 라디 칼 소거활성은 다음 식에서와 같이 실험구와 음성 대조구의 흡광도를 구하여 백분율(\%)로 표시하였으며 3회 반복하여 평균값으로 나타내었다.

\section{ABTS 라디칼 소거 활성}

$7 \mathrm{mM}$ ABTS 라디칼 $5 \mathrm{~mL}$ 과 $280 \mathrm{mM} \mathrm{K} \mathrm{S}_{2} \mathrm{O}_{8} 88 \mu \mathrm{L}$ 를 섞어 어두운 곳에 14-16시간 방치시킨 후, 이를 무수 에탄올 과 약 $1: 88$ 비율로 섞어 $734 \mathrm{~nm}$ 에서 대조구의 흡광도 값이 $0.7 \pm 0.02$ 가 되도록 조절한 $\mathrm{ABTS}$ 라디칼 용액을 사용하였 다. 적당히 희석한 추출물 $0.1 \mathrm{~mL}$ 와 $\mathrm{ABTS}$ 라디칼 용액 $0.9 \mathrm{~mL}$ 를 혼합하여 10 초간 vortex 후 3 분간 반응시켜 734 $\mathrm{nm}$ 에서 흡광도를 측정하였다(5). ABTS cation(ABTs ${ }^{+}$) 라 디칼 소거활성은 실험구와 음성 대조구의 흡광도를 구하여 아래 식에서와 같이 백분율 $(\%)$ 로 표시하였다. 각 실험은 3회 반복하여 평균값으로 나타내었다.

\section{Ferric Reducing/Antioxidant Power(FRAP)}

FRAP 분석은 Hwang 등(5)의 방법을 사용하여 청국장의 항산화력을 측정하였다. FRAP 시약은 acetate buffer(30 $\mathrm{mM}, \mathrm{pH}$ 3.6), TPTZ 시약 $(10 \mathrm{mM}$ in $40 \mathrm{mM} \mathrm{HCl})$ 및 $\mathrm{FeCl}_{3}$
용액(20 mM in DW)을 10:1:1(v/v/v)의 부피 비율로 혼합하 여 조제하였으며, $37^{\circ} \mathrm{C}$ 에서 15 분간 반응시켰다. 적당히 희 석한 추출물 $50 \mu \mathrm{L}$ 와 $\mathrm{FRAP}$ 시약 $950 \mu \mathrm{L}$ 를 시험관에 분주한 후 10 초간 vortex하여 $37^{\circ} \mathrm{C}$ 에서 15 분간 반응시키고 분광광 도계(Spectronic 2D)를 사용하여 $590 \mathrm{~nm}$ 에서 흡광도를 측 정하였다. 각 실험은 3회 반복하여 수행하여 평균값으로 나타내었다.

관능평가

관능평가는 관능평가의 목적, 시료 등에 대해서 우선 시 험자들에게 사전 인지시킨 후 1 차적인 관능평가가 실시를 통하여 최종 선별력이 우수한 함양농협가공사업소 직원 10 명과 경남과학기술대학교 식품과학부 학생 20 명을 대상 으로 '매우 좋다 5점, 좋다 4점, 보통이다 3점, 나쁘다 2점 및 매우 나쁘다 1점'으로 하는 5점 척도법으로 평가하였다.

\section{통계처리}

각 실험은 3회 반복 수행하였으며, 실험 결과는 SPSS 12.0 package를 사용하여 분산 분석을 수행하여 평균표준 편차로 나타내었다. 각 실험 분석 결과에 대한 유의성 검정 은 분산 분석 후 $\mathrm{p}<0.05$ 수준에서 Dumcan's multiple range test를 실시하였다.

\section{결과 및 고찰}

발효 중 생균수 및 $\beta-g l u c o s i d a s e$ 활성 변화

청국장 발효 중 생균수와 $\beta$-glucosidase 활성 변화는 Tables 1과 같았다. 청국장 발효 $48 \mathrm{hr}$ 까지 생균수와 $\beta$ -glucosidase 활성이 증가한 후 발효 종기 $(72 \mathrm{hr})$ 에는 약간 감소하였다. 여주가 첨가되지 않은 일반 청국장은 6.98 $\mathrm{cfu} / \mathrm{mL}$ 에서 $10.73 \mathrm{cfu} / \mathrm{mL}$ 까지 증가하였고 여주 첨가 청국 장 역시 발효 초기 $6.94 ~ 6.99 \mathrm{cfu} / \mathrm{mL}$ 수준에서 10.61 10.78 $\mathrm{cfu} / \mathrm{mL}$ 수준으로 증가하였다(Table 1). 한편 이에 상응하여 일반 청국장은 $5.8 \mathrm{unit} / \mathrm{g}$ 에서 $23.1 \mathrm{unit} / \mathrm{g}$ 으로 증가하였고 여주 첨가 청국장은 $5.6 \mathrm{unit} / \mathrm{g} 6.0 \mathrm{unit} / \mathrm{g}$ 수준에서 23.1 unit/g 23.4 unit/g 수준으로 증가하였다(Table 1). 이 결과로 부터 여주 첨가에 따른 청국장 발효 중 균 성장과 $\beta$ -glucosidase 활성에 영향을 미치지 않는 것으로 판단되었 다. Bacillus 종은 나토, 청국장 및 된장 등의 콩 발효에 관여하는 대표적인 균으로 알려져 있으며, 여러 연구에서 청국장 발효 중 Bacillus spp.의 생균수 증가에 의존하여 B-glucosidase 활성이 증가한다고 보고되고 있다 $(1,2,5$, 20,22).

발효 중 총 phenolics 및 isoflavone 함량 변화

Fig. 1에 보는 바와 같이, 여주 첨가량이 증가할수록 총 
Table 1. Changes in the viable cell number and $\beta$ glucosidase activity during the fermentation of Cheonggukjang without and with BMP using B. subtilis CSY191

\begin{tabular}{|c|c|c|c|c|c|}
\hline \multirow{2}{*}{$\begin{array}{c}\text { Cheonggukjang with BMP } \\
(\%)^{1)}\end{array}$} & \multicolumn{5}{|c|}{ Fermentation time (hr) } \\
\hline & 0 & 12 & 24 & 48 & 72 \\
\hline \multicolumn{6}{|c|}{ Viable cell numbers $\left.{ }^{2}\right)(\log \mathrm{CFU} / \mathrm{g})$} \\
\hline $0 \%$ & $6.98 \pm 0.34^{\mathrm{c}}$ & $8.63 \pm 0.35^{b}$ & $9.81 \pm 0.38^{\mathrm{ab}}$ & $10.89 \pm 0.41^{\mathrm{a}}$ & $10.73 \pm 0.48^{\mathrm{a}}$ \\
\hline $1.0 \%$ & $6.96 \pm 0.28^{c}$ & $8.64 \pm 0.45^{\mathrm{b}}$ & $9.73 \pm 0.48^{\mathrm{ab}}$ & $10.77 \pm 0.43^{\mathrm{a}}$ & $10.61 \pm 0.51^{\mathrm{a}}$ \\
\hline $2.5 \%$ & $6.94 \pm 0.29^{c}$ & $8.63 \pm 0.35^{b}$ & $9.76 \pm 0.39^{\mathrm{ab}}$ & $10.90 \pm 0.44^{\mathrm{a}}$ & $10.78 \pm 0.55^{\mathrm{a}}$ \\
\hline $5.0 \%$ & $6.99 \pm 0.34^{\mathrm{c}}$ & $8.71 \pm 0.45^{\mathrm{b}}$ & $9.74 \pm 0.39^{\mathrm{ab}}$ & $10.92 \pm 0.43^{\mathrm{a}}$ & $10.77 \pm 0.49^{\mathrm{a}}$ \\
\hline \multicolumn{6}{|l|}{ B-Glucosidase activity) (unit/g) } \\
\hline $0 \%$ & $5.8 \pm 0.12^{\mathrm{d}}$ & $18.0 \pm 0.22^{c}$ & $22.2 \pm 0.25^{\mathrm{ab}}$ & $24.4 \pm 0.21^{\mathrm{a}}$ & $23.1 \pm 0.20^{\mathrm{a}}$ \\
\hline $1.0 \%$ & $5.6 \pm 0.11^{\mathrm{d}}$ & $17.2 \pm 0.20^{c}$ & $21.8 \pm 0.23^{b}$ & $24.0 \pm 0.22^{\mathrm{a}}$ & $23.4 \pm 0.21^{\mathrm{a}}$ \\
\hline $2.5 \%$ & $5.9 \pm 0.12^{\mathrm{d}}$ & $18.2 \pm 0.19^{c}$ & $22.3 \pm 0.24^{\mathrm{ab}}$ & $24.7 \pm 0.23^{\mathrm{a}}$ & $23.2 \pm 0.20^{\mathrm{a}}$ \\
\hline $5.0 \%$ & $6.0 \pm 0.13^{\mathrm{d}}$ & $17.9 \pm 0.21^{\mathrm{c}}$ & $21.7 \pm 0.20^{\mathrm{b}}$ & $24.5 \pm 0.22^{\mathrm{a}}$ & $23.1 \pm 0.22^{\mathrm{a}}$ \\
\hline
\end{tabular}

${ }^{1)}$ Cheonggukjang fermented without BMP and with 1 5\% (w/w) of BMP.

${ }^{2)}$ All values are means of determinations in three independent experiments. Means with different lowercase letters $(a, b, a n d)$ indicate significant $(p<0.05)$ differences of fermentation times by Tukey's multiple range test.

${ }^{3)}$ All values are means of determinations in three independent experiments. Means with different lowercase letters (a, b, c, and d) indicate significant $(p<0.05)$ differences of fermentation times by Tukey's multiple range test. One unit of $\beta$-Glucosidase activity was defined as the amount of enzyme that liberated $1 \mu \mathrm{M}$ of $p$-NPG.

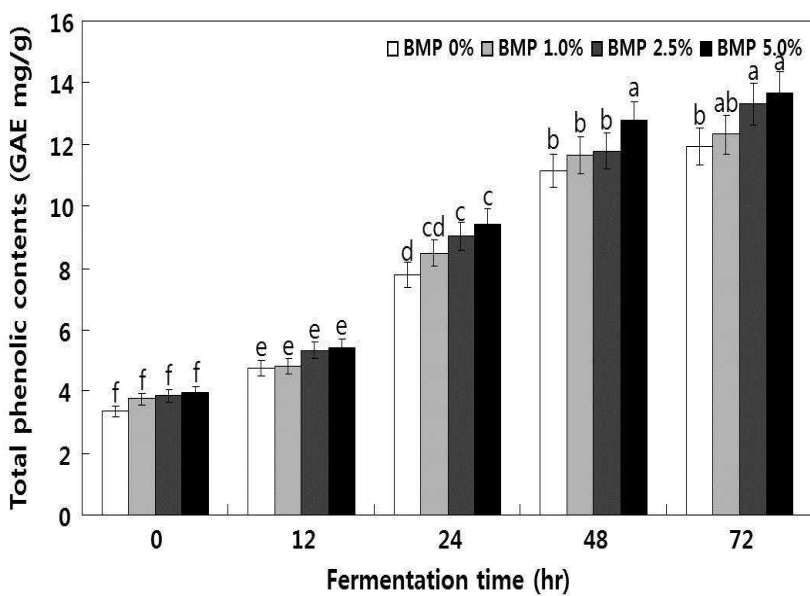

Fig. 1. Changes in the total phenolic contents during the fermentation of Cheonggukjang without and with BMP using $B$. subtilis CSY191.

All values are means of determinations in three independent experiments. Means with different lowercase letters $(a, b, c, d, e$, and $f)$ indicate significant $(p<0.05)$ differences of fermentation times by Tukey's multiple range test.

phenolics 함량이 높았고 청국장 발효 중 총 phenolics 함량 은 급격하게 증가하였다. 여주 무첨가 청국장은 발효 초기 $(0 \mathrm{hr}) 3.36 \mathrm{mg} / \mathrm{g} \mathrm{d} . \mathrm{w}$.에서 $11.93 \mathrm{mg} / \mathrm{g} \mathrm{d}$.w.까지 증가하였고 여주 첨가 청국장 역시 발효 중 $4.82 \mathrm{mg} / \mathrm{g} \mathrm{d} . \mathrm{w} \sim 5.42 \mathrm{mg} / \mathrm{g}$ d.w. 수준에서 발효 종기 $(72 \mathrm{hr}) 12.31 \mathrm{mg} / \mathrm{g} \mathrm{d} . \mathrm{w} \sim 13.66 \mathrm{mg} / \mathrm{g}$ d.w. 수준으로 증가하였다. 특히 여주 첨가량 $5.0 \%$ 가 가장 높은 총 phenolics 함량을 보였다(Fig. 1).

Phenolics 화합물은 보통 식물계에 널리 존재하고 수산기 와 당이 결합한 형태로 인체에 다양한 생리활성을 나타내며 $(23,24)$. 항산화 활성에 관여하는 것으로 알려져 있다 $(1,2)$.
콩 및 여주의 총 phenolics 함량 증가는 미생물의 효소 반응 에 의하여 유리 phenolics 함량이 증가하고 이에 따라 항산 화 활성이 증가한 것으로 판단되었다. 이전에 많은 연구자 들이 청국장 발효 중 총 phenolics 함량이 증가는 미생물 유래 $\beta$-glucosidase 혹은 esterase 등의 효소 반응에 의한 결과로 보고하여 본 연구 결과와 동일하였다 $(1,2,5,20,22)$. 몇몇 연구에서 콩과 콩 가공식품의 주요 phenolics 화합물로 gallic, protocatechuic, p-cumaric, caffeic, chlorogenic, gentisic, p-hydroxylbenzoic, vanilic 및 ferulic acids로 보고하 였고(3,20,22,25-27) 특히, Cho 등(20)은 잠재적인 생균제재 인 B. subtilis $\mathrm{CS} 90$ 의해 발효된 청국장의 flavanol의 catechin 및 epicatechin과 phenolics acid의 gallic acid가 발효 종기 높은 수준으로 증가하였다고 보고하였다. 한편 블랙푸드 (흑임자, 흑미 및 다시마), 흑마늘, 마늘, 녹차, 당귀, 지황 및 홍삼 첨가 청국장의 경우 본 연구와 유사하게 일반 청국 장보다 높은 phenolics 함량을 나타내었다 $(2,4,6,9,28)$. Choi 등(23)은 여주의 phenolic acid(gallic, protocatechuic, $\rho$ -Hydroxylbenzoic, vanillic, caffeic, chlorogenic, $\rho$-cumaric 및 ferulic acids) 및 flavan-3-ol(epigallocatechin, catechin 및 epicatechin) 보고하였으며, 이들 대부분 화합물은 강력한 항산화제로 알려져 있다.

여주 첨가량에 따른 isoflavone의 HPLC 크로마토그램 및 함량 변화를 살펴본 결과 Figs. 2 3 및 Table 2와 같았다. HPLC 크로마토그램 분석 결과 발효 전 $(0 \mathrm{hr})$ 의 경우 총 9종의 isoflavone 유도체(daidzin, glycitin, genistin, malonyldaidzin, malonylglycitin, malonygenistin, acetyldaidzin, acetylglycitin, daidzein, glycitein 및 genistein)가 검출되었고 발효 후 $(72 \mathrm{hr})$ acetyldaidzin의 1 종 더 검출되어 총 10 종의 
Table 2. Changes in the isoflavone contents during the fermentation of Cheonggukjang without and with BMP using B. subtilis CSY191

\begin{tabular}{|c|c|c|c|c|c|c|c|c|c|c|c|c|c|c|}
\hline \multirow{3}{*}{$\begin{array}{l}\text { Cheongguk- } \\
\text { jang with } \\
\text { BMP }(\%)^{1)}\end{array}$} & \multirow{3}{*}{$\begin{array}{l}\text { Fermentation } \\
\text { time (hr) }\end{array}$} & \multicolumn{12}{|c|}{ Isoflavone contents ${ }^{2)}(\mu \mathrm{g} / \mathrm{g})$} & \multirow{3}{*}{ Total } \\
\hline & & \multicolumn{3}{|c|}{ Glycosides } & \multicolumn{3}{|c|}{ Malonylglycosides } & \multicolumn{3}{|c|}{ Acetylglycosides } & \multicolumn{3}{|c|}{ Aglycones } & \\
\hline & & Daidzin & Glycitin & Genistin & Daidzin & Glycitin & Genistin & Daidzin & Glycitin & Genistin & Daidzein & Glycitein & Genistein & \\
\hline \multirow{5}{*}{$0 \%$} & 0 & $\begin{array}{l}570.77 \\
\pm 22.83^{\mathrm{a}}\end{array}$ & $\begin{array}{l}224.63 \\
\pm 11.23^{\mathrm{bc}}\end{array}$ & $\begin{array}{l}589.16 \\
\pm 23.57^{\mathrm{ab}}\end{array}$ & $\begin{array}{l}91.02 \\
\pm 3.64^{\mathrm{b}}\end{array}$ & $\begin{array}{l}31.06 \\
\pm 1.55^{\mathrm{d}}\end{array}$ & $\begin{array}{l}144.56 \\
\pm 5.78^{\mathrm{b}}\end{array}$ & $\mathrm{nd}^{3}$ & nd & nd & $\begin{array}{l}30.98 \\
\pm 1.24^{\mathrm{e}}\end{array}$ & $\begin{array}{l}86.78 \\
\pm 4.34^{\mathrm{a}}\end{array}$ & $\begin{array}{l}33.85 \\
\pm 1.35^{\mathrm{a}}\end{array}$ & $\begin{array}{l}1802.81 \\
\pm 72.11^{\mathrm{a}}\end{array}$ \\
\hline & 12 & $\begin{array}{l}558.91 \\
\pm 27.95^{\mathrm{a}}\end{array}$ & $\begin{array}{l}266.72 \\
\pm 1067^{b}\end{array}$ & $\begin{array}{c}581.48 \\
\pm 29.07^{\mathrm{ab}}\end{array}$ & $\begin{array}{c}116.1 \\
\pm 5.81^{\mathrm{ab}}\end{array}$ & $\begin{array}{c}54.39 \\
\pm 2.18^{\mathrm{bc}}\end{array}$ & $\begin{array}{l}177.88 \\
\pm 8.85^{\mathrm{a}}\end{array}$ & nd & nd & nd & $\begin{array}{l}127.88 \\
\pm 6.39^{d}\end{array}$ & $\begin{array}{l}72.35 \\
\pm 2.89^{\mathrm{a}}\end{array}$ & $\begin{array}{l}26.81 \\
\pm 1.34^{\mathrm{ab}}\end{array}$ & $\begin{array}{l}1982.52 \\
\pm 99.13^{\mathrm{a}}\end{array}$ \\
\hline & 24 & $\begin{array}{l}376.23 \\
\pm 15.05^{\mathrm{b}}\end{array}$ & $\begin{array}{l}186.27 \\
\pm 9.31^{\mathrm{c}}\end{array}$ & $\begin{array}{l}432.79 \\
\pm 17.31^{\mathrm{b}}\end{array}$ & $\begin{array}{l}118.70^{\mathrm{b}} \\
\pm 4.75^{\mathrm{a}}\end{array}$ & $\begin{array}{l}46.57 \\
\pm 2.33^{\mathrm{c}}\end{array}$ & $\begin{array}{l}177.61 \\
\pm 7.10^{\mathrm{a}}\end{array}$ & nd & nd & nd & $\begin{array}{c}261.28 \\
\pm 10.45^{\mathrm{bc}}\end{array}$ & $\begin{array}{l}56.39 \\
\pm 2.82^{b}\end{array}$ & $\begin{array}{l}33.77 \\
\pm 1.35^{\mathrm{a}}\end{array}$ & $\begin{array}{l}1689.61 \\
\pm 84.48^{\mathrm{b}}\end{array}$ \\
\hline & 48 & $\begin{array}{l}249.91 \\
\pm 10.00^{c}\end{array}$ & $\begin{array}{l}182.53 \\
\pm 9.13^{c}\end{array}$ & $\begin{array}{l}250.91 \\
\pm 10.04^{\mathrm{c}}\end{array}$ & $\begin{array}{l}125.77 \\
\pm 5.03^{\mathrm{a}}\end{array}$ & $\begin{array}{l}84.78 \\
\pm 4.24^{b}\end{array}$ & $\begin{array}{l}146.84 \\
\pm 5.87^{\mathrm{b}}\end{array}$ & $\begin{array}{r}19.35 \\
\pm 0.77^{\mathrm{b}}\end{array}$ & nd & nd & $\begin{array}{l}369.15 \\
\pm 14.77^{\mathrm{b}}\end{array}$ & $\begin{array}{l}34.07 \\
\pm 1.70^{c}\end{array}$ & $\begin{array}{l}29.48 \\
\pm 1.18^{\mathrm{a}}\end{array}$ & $\begin{array}{l}1492.79 \\
\pm 74.67^{\circ}\end{array}$ \\
\hline & 72 & $\begin{array}{c}249.66 \\
\pm 9.99\end{array}$ & $\begin{array}{l}273.21 \\
\pm 13.66^{b}\end{array}$ & $\begin{array}{l}217.42 \\
\pm 8.70^{\mathrm{bc}}\end{array}$ & $\begin{array}{l}126.71 \\
\pm 5.07^{\mathrm{a}}\end{array}$ & $\begin{array}{l}115.23 \\
\pm 5.76^{\mathrm{a}}\end{array}$ & $\begin{array}{l}134.66 \\
\pm 5.39^{\mathrm{b}}\end{array}$ & $\begin{array}{l}40.21 \\
\pm 1.1^{6 \mathrm{a}}\end{array}$ & nd & nd & $\begin{array}{l}563.32 \\
\pm 22.53^{\mathrm{a}}\end{array}$ & $\begin{array}{l}21.28 \\
\pm 1.06^{\mathrm{cd}}\end{array}$ & $\begin{array}{l}14.31 \\
\pm 0.57^{\mathrm{c}}\end{array}$ & $\begin{array}{l}1756.01 \\
\pm 70.24^{\mathrm{b}}\end{array}$ \\
\hline \multirow{5}{*}{$1.0 \%$} & 0 & $\begin{array}{l}612.92 \\
\pm 24.52^{\mathrm{a}}\end{array}$ & $\begin{array}{l}214.11 \\
\pm 10.71^{\mathrm{bc}}\end{array}$ & $\begin{array}{l}662.03 \\
\pm 26.48^{\mathrm{a}}\end{array}$ & $\begin{array}{c}98.61 \\
\pm 3.94^{\mathrm{b}}\end{array}$ & $\begin{array}{l}31.80 \\
\pm 1.59^{d}\end{array}$ & $\begin{array}{l}157.28 \\
\pm 6.29^{\mathrm{ab}}\end{array}$ & nd & nd & nd & $\begin{array}{l}29.62 \\
\pm 1.18^{\mathrm{e}}\end{array}$ & $\begin{array}{l}82.10 \\
\pm 4.11^{\mathrm{a}}\end{array}$ & $\begin{array}{l}25.48 \\
\pm 1.02^{\mathrm{ab}}\end{array}$ & $\begin{array}{l}1913.95 \\
\pm 76.56^{\mathrm{a}}\end{array}$ \\
\hline & 12 & $\begin{array}{l}568.71 \\
\pm 28.44^{\mathrm{a}}\end{array}$ & $\begin{array}{l}223.37 \\
\pm 8.93^{\mathrm{bc}}\end{array}$ & $\begin{array}{l}603.28 \\
\pm 30.16^{\mathrm{ab}}\end{array}$ & $\begin{array}{l}109.87 \\
\pm 4.39^{\mathrm{ab}}\end{array}$ & $\begin{array}{l}37.46 \\
\pm 1.87^{\mathrm{c}}\end{array}$ & $\begin{array}{l}175.11 \\
\pm 7.00^{\mathrm{a}}\end{array}$ & nd & nd & nd & $\begin{array}{l}114.09 \\
\pm 4.56^{\mathrm{d}}\end{array}$ & $\begin{array}{l}72.88 \\
\pm 3.64^{\mathrm{a}}\end{array}$ & $\begin{aligned} & 19.99 \\
\pm & 0.80^{b}\end{aligned}$ & $\begin{array}{l}1924.76 \\
\pm 96.24^{\mathrm{a}}\end{array}$ \\
\hline & 24 & $\begin{array}{l}423.57 \\
\pm 16.94^{\mathrm{b}}\end{array}$ & $\begin{array}{l}205.85 \\
\pm 10.29^{c}\end{array}$ & $\begin{array}{l}441.26 \\
\pm 17.65^{\mathrm{b}}\end{array}$ & $\begin{array}{l}97.13 \\
\pm 3.89^{b}\end{array}$ & $\begin{array}{l}44.38 \\
\pm 2.22^{\mathrm{c}}\end{array}$ & $\begin{array}{l}149.84 \\
\pm 5.99^{\mathrm{b}}\end{array}$ & nd & nd & nd & $\begin{array}{l}217.27 \\
\pm 8.69^{c}\end{array}$ & $\begin{array}{l}57.48 \\
\pm 2.87^{b}\end{array}$ & $\begin{array}{l}27.61 \\
\pm 1.10^{\mathrm{ab}}\end{array}$ & $\begin{array}{l}1664.39 \\
\pm 83.22^{\mathrm{bc}}\end{array}$ \\
\hline & 48 & $\begin{array}{l}281.63 \\
\pm 14.08^{c}\end{array}$ & $\begin{array}{l}206.63 \\
\pm 8.27^{c}\end{array}$ & $\begin{array}{l}287.00 \\
\pm 14.35^{\mathrm{bc}}\end{array}$ & $\begin{array}{l}142.54 \\
\pm 7.13^{\mathrm{a}}\end{array}$ & $\begin{array}{l}85.08 \\
\pm 3.40^{b}\end{array}$ & $\begin{array}{l}165.96 \\
\pm 8.30^{\mathrm{ab}}\end{array}$ & $\begin{array}{c}19.38 \\
\pm 0.78^{b}\end{array}$ & nd & nd & $\begin{array}{l}378.21 \\
\pm 15.13^{\mathrm{ab}}\end{array}$ & $\begin{array}{l}36.23 \\
\pm 1.81^{c}\end{array}$ & $\begin{array}{l}31.05 \\
\pm 1.24^{\mathrm{a}}\end{array}$ & $\begin{array}{l}1633.71 \\
\pm 65.35^{\text {bc }}\end{array}$ \\
\hline & 72 & $\begin{array}{l}259.19 \\
\pm 10.37^{\circ}\end{array}$ & $\begin{array}{l}359.58 \\
\pm 17.98\end{array}$ & $\begin{array}{l}248.44 \\
\pm 9.94^{c}\end{array}$ & $\begin{array}{l}124.46 \\
\pm 4.98^{\mathrm{a}}\end{array}$ & $\begin{array}{l}102.25 \\
\pm 5.11^{\mathrm{a}}\end{array}$ & $\begin{array}{l}141.52 \\
\pm 5.66^{b}\end{array}$ & $\begin{array}{l}22.91 \\
\pm 0.92^{\mathrm{b}}\end{array}$ & nd & nd & $\begin{array}{l}437.32 \\
\pm 17.49^{\mathrm{b}}\end{array}$ & $\begin{array}{l}23.02 \\
\pm 1.15^{\mathrm{cd}}\end{array}$ & $\begin{array}{l}22.82 \\
\pm 0.91^{\mathrm{b}}\end{array}$ & $\begin{array}{l}1741.51 \\
\pm 87.08^{b}\end{array}$ \\
\hline \multirow{5}{*}{$2.5 \%$} & 0 & $\begin{array}{l}607.98 \\
\pm 24.32^{\mathrm{a}}\end{array}$ & $\begin{array}{l}219.47 \\
\pm 10.98^{\mathrm{bc}}\end{array}$ & $\begin{array}{l}636.51 \\
\pm 25.46^{\mathrm{a}}\end{array}$ & $\begin{array}{l}56.52 \\
\pm 2.26^{c}\end{array}$ & $\begin{array}{l}28.19 \\
\pm 1.14^{d}\end{array}$ & $\begin{array}{l}103.01 \\
\pm 4.12^{\text {cd }}\end{array}$ & nd & nd & nd & $\begin{array}{l}22.57 \\
\pm 0.90^{\mathrm{f}}\end{array}$ & $\begin{array}{l}32.14 \\
\pm 1.61^{\mathrm{c}}\end{array}$ & $\begin{array}{l}20.38 \\
\pm 0.82^{\mathrm{b}}\end{array}$ & $\begin{array}{l}1726.77 \\
\pm 69.07^{\circ}\end{array}$ \\
\hline & 12 & $\begin{array}{l}542.03 \\
\pm 21.68^{\mathrm{a}}\end{array}$ & $\begin{array}{l}216.66 \\
\pm 10.83^{\mathrm{bc}}\end{array}$ & $\begin{array}{l}543.89 \\
\pm 21.76^{\mathrm{b}}\end{array}$ & $\begin{array}{l}90.67 \\
\pm 3.36^{b}\end{array}$ & $\begin{array}{l}30.85 \\
\pm 1.54^{\mathrm{d}}\end{array}$ & $\begin{array}{l}147.84 \\
\pm 5.91^{\mathrm{b}}\end{array}$ & nd & nd & nd & $\begin{array}{l}83.49 \\
\pm 3.34\end{array}$ & $\begin{array}{l}60.50 \\
\pm 3.03^{\mathrm{b}}\end{array}$ & $\begin{array}{l}14.87 \\
\pm 0.59^{\mathrm{c}}\end{array}$ & $\begin{array}{l}1730.80 \\
\pm 86.54^{\mathrm{b}}\end{array}$ \\
\hline & 24 & $\begin{array}{l}414.72 \\
\pm 20.74^{\mathrm{b}}\end{array}$ & $\begin{array}{l}209.10 \\
\pm 8.36^{c}\end{array}$ & $\begin{array}{l}435.23 \\
\pm 21.76^{b}\end{array}$ & $\begin{array}{l}106.37 \\
\pm 5.32^{\mathrm{ab}}\end{array}$ & $\begin{array}{c}49.98 \\
\pm 2.00^{\mathrm{bc}}\end{array}$ & $\begin{array}{l}146.83 \\
\pm 7.34^{b}\end{array}$ & nd & nd & nd & $\begin{array}{l}194.56 \\
\pm 7.78^{\mathrm{c}}\end{array}$ & $\begin{array}{c}46.64 \\
\pm 2.33^{\mathrm{bc}}\end{array}$ & $\begin{array}{l}21.22 \\
\pm 0.85^{b}\end{array}$ & $\begin{array}{l}1624.65 \\
\pm 64.99^{\text {bc }}\end{array}$ \\
\hline & 48 & $\begin{array}{l}256.17 \\
\pm 10.25^{\mathrm{c}}\end{array}$ & $\begin{array}{l}173.08 \\
\pm 8.65^{\mathrm{c}}\end{array}$ & $\begin{array}{l}258.07 \\
\pm 10.32^{\mathrm{c}}\end{array}$ & $\begin{array}{l}122.97 \\
\pm 4.92^{\mathrm{a}}\end{array}$ & $\begin{array}{l}87.05 \\
\pm 4.35^{b}\end{array}$ & $\begin{array}{l}144.43 \\
\pm 5.78^{\mathrm{b}}\end{array}$ & $\begin{array}{l}22.86 \\
\pm 0.91^{\mathrm{b}}\end{array}$ & nd & nd & $\begin{array}{l}412.96 \\
\pm 20.65^{\mathrm{b}}\end{array}$ & $\begin{array}{l}22.39 \\
\pm 0.90^{\text {cd }}\end{array}$ & $\begin{array}{c}25.87 \\
\pm 23.06^{\mathrm{ab}}\end{array}$ & $\begin{array}{l}1525.85 \\
\pm 76.29^{c}\end{array}$ \\
\hline & 72 & $\begin{array}{l}218.69 \\
\pm 8.75^{c}\end{array}$ & $\begin{array}{l}223.95 \\
\pm 11.20^{\mathrm{bc}}\end{array}$ & $\begin{array}{l}188.68 \\
\pm 7.55^{\mathrm{d}}\end{array}$ & $\begin{array}{l}97.43 \\
\pm 3.90^{\mathrm{b}}\end{array}$ & $\begin{array}{l}79.82 \\
\pm 3.99^{b}\end{array}$ & $\begin{array}{l}115.38 \\
\pm 4.62^{c}\end{array}$ & $\begin{array}{c}9.28 \\
\pm 0.37^{\mathrm{d}}\end{array}$ & nd & nd & $\begin{array}{r}395.23 \\
\pm 15.81^{\mathrm{b}} \\
\end{array}$ & $\begin{array}{l}15.67 \\
\pm 0.78^{d} \\
\end{array}$ & $\begin{array}{c}26.09 \\
\pm 1.04^{\mathrm{ab}} \\
\end{array}$ & $\begin{array}{l}1370.22 \\
\pm 54.81^{\mathrm{d}} \\
\end{array}$ \\
\hline \multirow{5}{*}{$5.0 \%$} & 0 & $\begin{array}{l}583.28 \\
\pm 23.33^{\mathrm{a}}\end{array}$ & $\begin{array}{l}259.44 \\
\pm 12.97^{\mathrm{b}}\end{array}$ & $\begin{array}{l}616.82 \\
\pm 24.67^{\mathrm{ab}}\end{array}$ & $\begin{array}{l}54.40 \\
\pm 2.18^{\mathrm{c}}\end{array}$ & $\begin{array}{c}33.89 \\
\pm 1.69^{\text {cd }}\end{array}$ & $\begin{array}{l}99.06 \\
\pm 3.96^{\text {cd }}\end{array}$ & nd & nd & nd & $\begin{array}{l}18.79 \\
\pm 0.75^{\mathrm{f}}\end{array}$ & $\begin{array}{l}90.43 \\
\pm 4.52^{\mathrm{a}}\end{array}$ & $\begin{array}{l}16.85 \\
\pm 0.67^{\circ}\end{array}$ & $\begin{array}{l}1772.96 \\
\pm 70.92^{b}\end{array}$ \\
\hline & 12 & $\begin{array}{l}571.35 \\
\pm 28.57^{\mathrm{a}}\end{array}$ & $\begin{array}{l}221.22 \\
\pm 8.85^{\mathrm{bc}}\end{array}$ & $\begin{array}{l}591.76 \\
\pm 29.59^{\mathrm{ab}}\end{array}$ & $\begin{array}{l}51.52 \\
\pm 2.58^{\mathrm{c}}\end{array}$ & $\begin{array}{l}27.06 \\
\pm 1.08^{d}\end{array}$ & $\begin{array}{l}92.40 \\
\pm 4.62^{\mathrm{d}}\end{array}$ & nd & nd & nd & $\begin{array}{l}48.11 \\
\pm 1.92^{\mathrm{e}}\end{array}$ & $\begin{array}{c}77.42 \\
\pm 3.87^{\mathrm{a}}\end{array}$ & $\begin{array}{l}15.96 \\
\pm 0.64^{\mathrm{c}}\end{array}$ & $\begin{array}{l}1696.80 \\
\pm 84.84^{\text {bc }}\end{array}$ \\
\hline & 24 & $\begin{array}{l}431.86 \\
\pm 17.27^{\mathrm{b}}\end{array}$ & $\begin{array}{l}224.76 \\
\pm 11.24^{\mathrm{bc}}\end{array}$ & $\begin{array}{l}454.72 \\
\pm 18.19^{b}\end{array}$ & $\begin{array}{c}61.82 \\
\pm 2.47^{\mathrm{bc}}\end{array}$ & $\begin{array}{l}29.52 \\
\pm 1.48^{d}\end{array}$ & $\begin{array}{l}93.35 \\
\pm 3.73^{\mathrm{d}}\end{array}$ & nd & nd & nd & $\begin{array}{l}168.30 \\
\pm 6.73^{\mathrm{cd}}\end{array}$ & $\begin{array}{l}55.23 \\
\pm 2.76^{b}\end{array}$ & $\begin{array}{l}18.69 \\
\pm 0.75^{b}\end{array}$ & $\begin{array}{l}1538.25 \\
\pm 61.53^{\mathrm{c}}\end{array}$ \\
\hline & 48 & $\begin{array}{l}319.76 \\
\pm 12.79^{\mathrm{bc}}\end{array}$ & $\begin{array}{l}446.70 \\
\pm 22.34^{\mathrm{a}}\end{array}$ & $\begin{array}{c}324.39 \\
\pm 12.98^{\mathrm{bc}}\end{array}$ & $\begin{array}{l}96.08 \\
\pm 3.84^{\mathrm{b}}\end{array}$ & $\begin{array}{c}63.70 \\
\pm 3.19^{\mathrm{bc}}\end{array}$ & $\begin{array}{l}112.09 \\
\pm 4.48^{c}\end{array}$ & $\begin{array}{c}8.28 \\
\pm 0.33^{\mathrm{d}}\end{array}$ & nd & nd & $\begin{array}{l}294.31 \\
\pm 11.77^{\mathrm{c}}\end{array}$ & $\begin{array}{l}37.13 \\
\pm 1.86^{c}\end{array}$ & $\begin{array}{l}24.65 \\
\pm 0.99^{\mathrm{ab}}\end{array}$ & $\begin{array}{l}1727.09 \\
\pm 86.35^{b}\end{array}$ \\
\hline & 72 & $\begin{array}{l}370.17 \\
\pm 18.51^{\mathrm{b}}\end{array}$ & $\begin{array}{l}276.68 \\
\pm 11.07^{\mathrm{b}}\end{array}$ & $\begin{array}{l}136.05 \\
\pm 6.80^{\mathrm{e}}\end{array}$ & $\begin{array}{c}83.43 \\
\pm 3.34^{\mathrm{b}}\end{array}$ & $\begin{array}{l}77.56 \\
\pm 3.88^{\mathrm{b}}\end{array}$ & $\begin{array}{l}96.88 \\
\pm 3.88^{\mathrm{cd}}\end{array}$ & $\begin{array}{l}14.03 \\
\pm 0.56^{\mathrm{c}}\end{array}$ & nd & nd & $\begin{array}{l}390.57 \\
\pm 15.62^{\mathrm{b}}\end{array}$ & $\begin{array}{l}26.25 \\
\pm 1.31^{\mathrm{cd}}\end{array}$ & $\begin{array}{l}36.22 \\
\pm 1.45^{\mathrm{a}}\end{array}$ & $\begin{array}{l}1507.84 \\
\pm 60.31^{\mathrm{c}}\end{array}$ \\
\hline
\end{tabular}

\footnotetext{
${ }^{1)}$ Cheonggukjang fermented without BMP and with $1-5 \%(\mathrm{w} / \mathrm{w})$ of BMP.

${ }^{2)}$ All values are means of determinations in three independent experiments. Means with different lowercase letters (a, b, $c, d$, and e) indicate significant ( $\left.p<0.05\right)$ differences of fermentation times by Tukey's multiple range test.

${ }^{3)}$ nd: not detected.
}

유도체가 검출되었다. 특히 청국장의 발효 초기 $(0 \mathrm{hr})$ 주요 피크로는 배당체(glycosides)인 diadzin(peak 1) 및 genistin (peak 3)이 검출되었고 발효 종기 $(72 \mathrm{hr}$ )에는 비배당체 중 daidzein(peak 9) 증가하였다(Fig. 2). 한편 발효 초기(0 hr) glycosides 비율은 $86.64 \% \sim 77.80 \%$, malonylglycosides
비율은 $5.88 \% \sim 14.79 \%$ 및 aglycones 비율 $4.58 \% \sim 8.41 \%$ 수준에서 glycosides 비율은 감소하였고 malonylglycosides 및 aglycones 함량은 증가하였고 acetylglycosides는 발효 $48 \mathrm{hr}$ 째 검출되어 발효 종기까지 증가하였고 특히 발효 종기 (72 hr) glycosides 비율은 각각 34.11\%(여주 무첨가), 

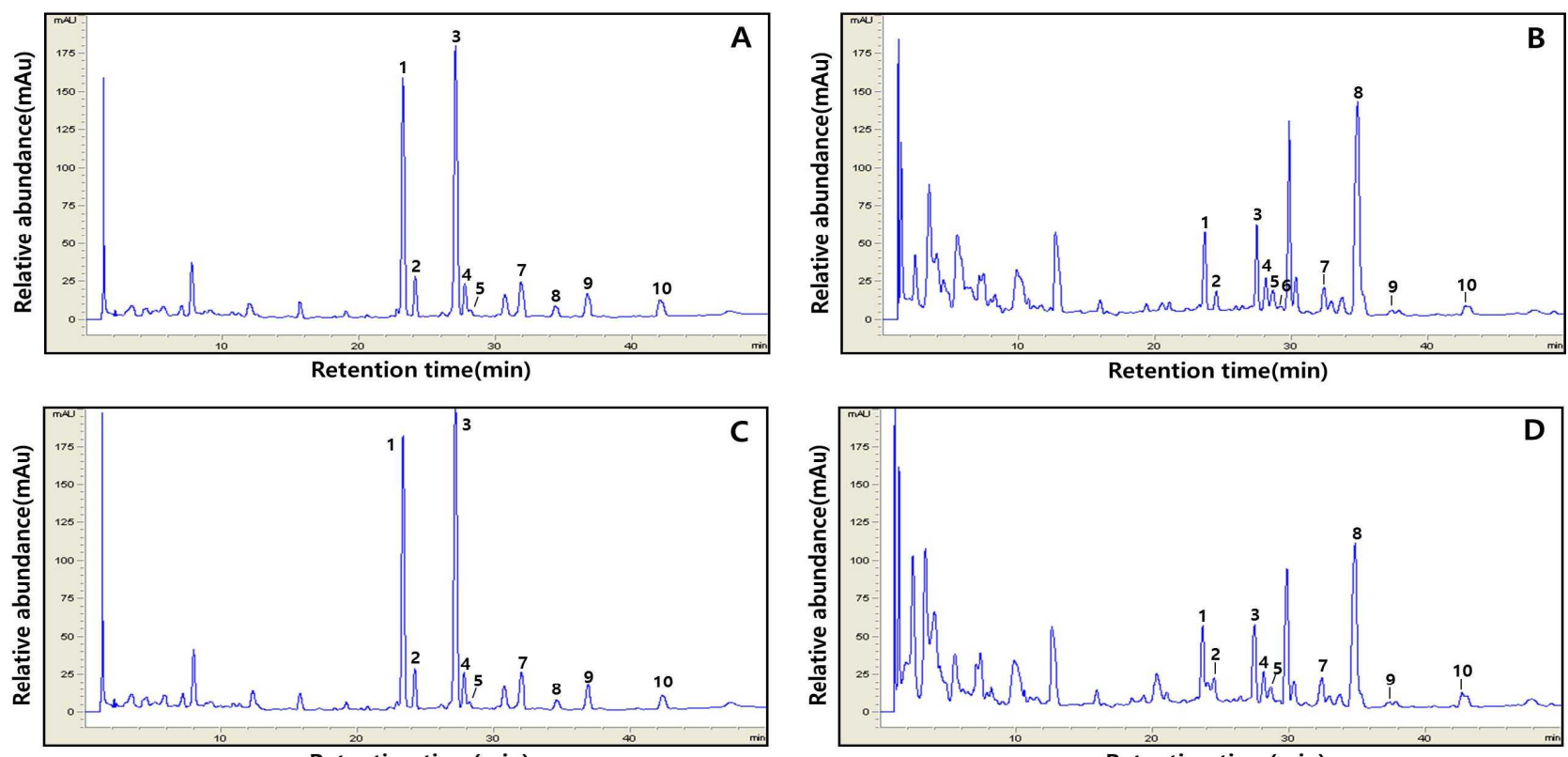

Retention time(min)

Retention time(min)
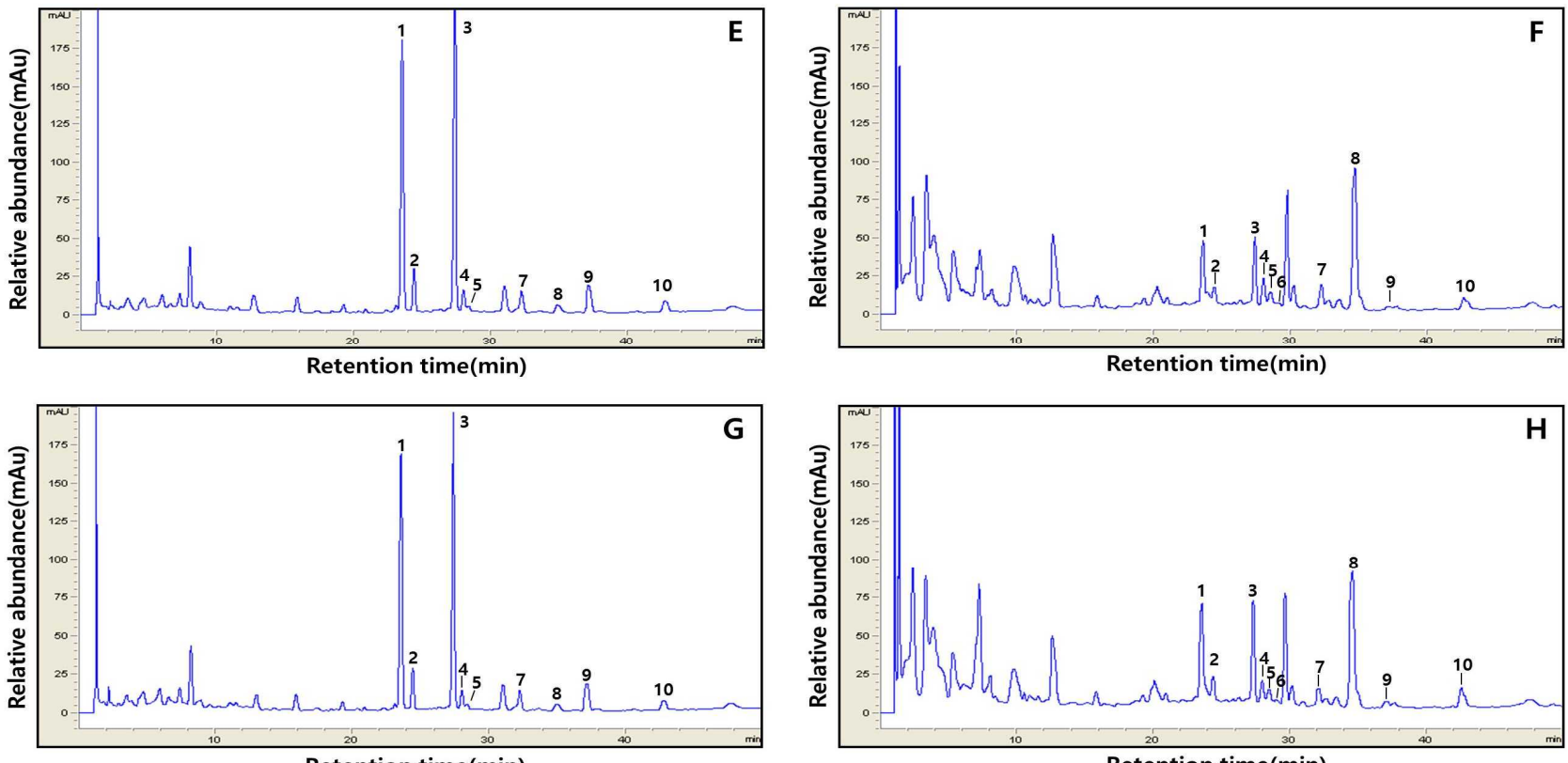

Fig. 2. Typical HPLC chromatograms of isoflavones.

A, Cheonggukjang fermented with BMP (0 hr); B, Cheonggukjang fermented with BMP (72 hr); C, Cheonggukjang fermented with 1\% (w/w) of BMP (0 hr); D, Cheonggukjang fermented with $1 \%(\mathrm{w} / \mathrm{w})$ of BMP (72 hr); E, Cheonggukjang fermented with 2.5\% (w/w) of BMP (0 hr); F, Cheonggukjang fermented with $2.5 \%(\mathrm{w} / \mathrm{w})$ of BMP (72 hr); G, Cheonggukjang fermented with 5\% (w/w) of BMP (0 hr); and H, Cheonggukjang fermented with 5\% (w/w) of BMP (72 hr). 1, daidzin; 2, glycitin; 3, genistin; 4, malonyldaidzin; 5, malonylglycitin; 6, acetyldaidzin; 7, malonylgenistin; 8, dadzein; 9, glycitein, and 10, genistein.

$27.74 \%$ (여주 $1 \%$ 첨가), $36.33 \%$ (여주 $2.5 \%$ 첨가) 및 $33.64 \%$ (여주 5\% 첨가)를 나타내었다(Fig. 3). Table 2와 같이, 총 isoflavone 함량은 발효 전보다는 발효 완료 후 감소하였으 나, isoflavone-aglycone 형태 중 daidzein은 증가하였다. 일 반 청국장(여주 무첨가)의 총 isoflavone 함량은 발효 초기(0 hr) $1,802.81 \mathrm{\mu g} / \mathrm{g}$ 에서 발효 $72 \mathrm{~h} \mathrm{후} \mathrm{약간} \mathrm{감소하여} 1,756.01$ $\mu \mathrm{g} / \mathrm{g}$ 이었으며, diadzin은 $570.77 \mu \mathrm{g} / \mathrm{g}(0 \mathrm{hr})$ 에서 $249.66 \mu$ $\mathrm{g} / \mathrm{g}(72 \mathrm{hr})$ 로 감소하였고 이와 상반되게 daidzein은 30.98 $\mu \mathrm{g} / \mathrm{g}$ 에서 $563.32 \mu \mathrm{g} / \mathrm{g}$ 로 증가하였다. 여주 첨가 청국장의 일반 청국장 동일한 경향을 나타냈으며, 발효 $0 \mathrm{hr}$ 째 diadzin 은 각각 $612.92 \mu \mathrm{g} / \mathrm{g}(1.0 \%), 607.98 \%(2.5 \%)$ 및 583.28(5.0\%) 에서 발효 종료 $72 \mathrm{hr}$ 감소하였고 비배당체인 diadzein은 각각 $437.32 \mu \mathrm{g} / \mathrm{g}(1.0 \%), 395.23 \%(2.5 \%)$ 및 390.57(5.0\%)로 증가하였다(Table 2).

일반적으로 콩 isoflavone의 경우 glycoside 형태로 존재 하며 이들은 미생물의 $\beta$-glycosidase 활성에 의해서 발효 

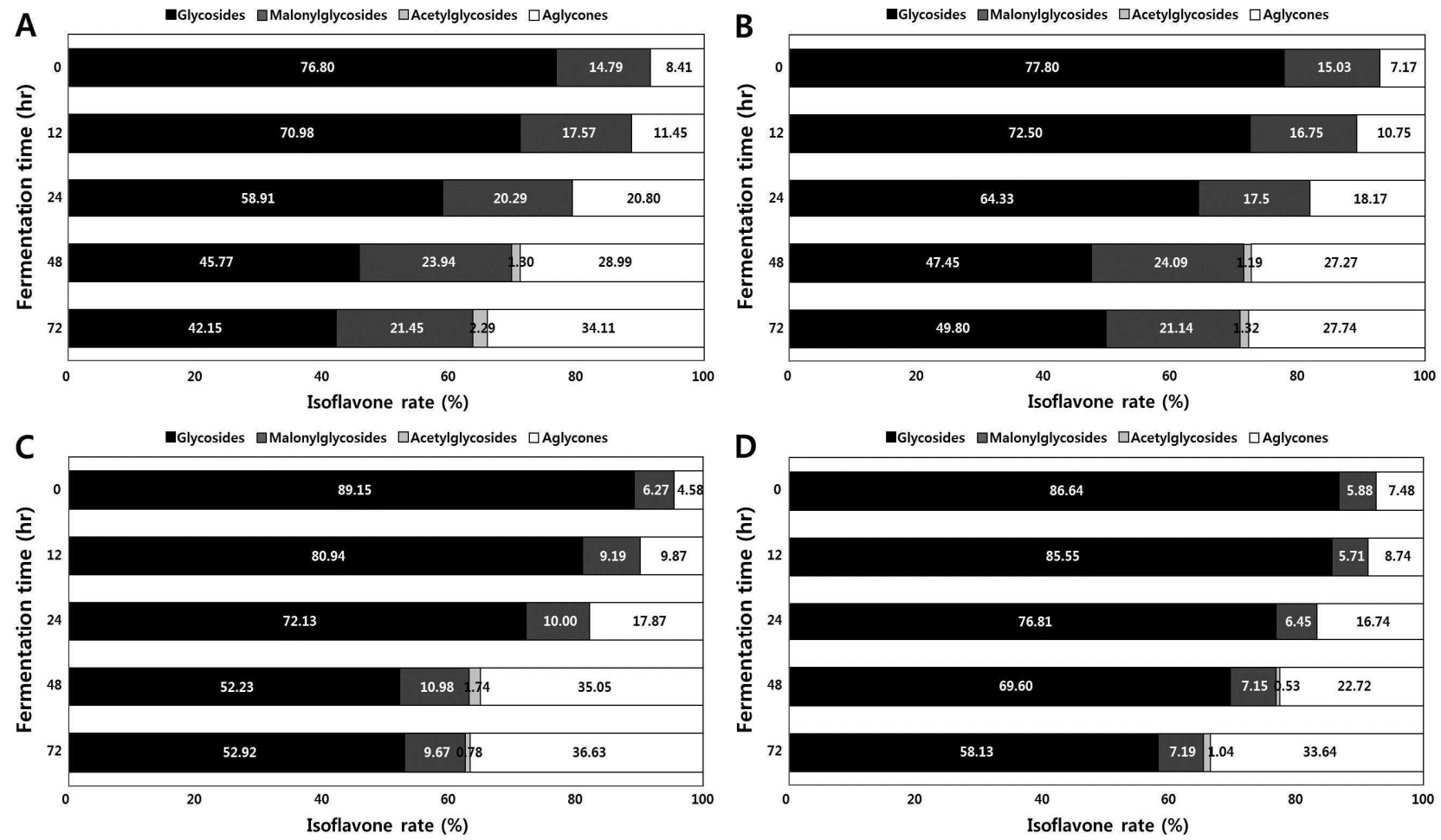

Fig. 3. Changes in the glycoside, malonylglycoside, acetylglycoside, and aglycone rates during the fermentation of Cheonggukjang without and with BMP using B. subtilis CSY191.

A, Cheonggukjang fermented with BMP; B, Cheonggukjang fermented with 1\% (w/w) of BMP; C, Cheonggukjang fermented with 2.5\% (w/w) of BMP; and D, Cheonggukjang fermented with $5 \%(\mathrm{w} / \mathrm{w})$ of $\mathrm{BMP}$

중 aglycone형태로 전환된다. Cho 등(21) 및 Shin 등(1)은 잠재적인 생균제제인 B. subtilis에 의한 청국장 발효 중 isoflavone-aglycone 함량의 증가한 결과는 $\beta$-glycosidase 활 성에 의한 것으로 보고하였으며, 최근에 $\operatorname{Kim}$ 등(2) 마늘 첨가 청국장 발효 중 $\beta$-glycosidase 활성이 증가함으로서 isoflavone-aglycone 함량이 증가한 것으로 보고하였다. 역 시 본 연구에서 B. subtilis CSY191 이용 여주 청국장 발효 중 $\beta$-glycosidase 활성 증가에 따라 배당체 화합물은 감소하 고 비배당체 함량이 증가한 것으로 판단되었다. 이에 반해 Yang 등(29)은 B. subtilis 이용 청국장 발효 중 $\beta$-glycosidase 활성에 영향을 미치지 않으며 aglycone 함량은 증가하지 않는다고 보고하였다. Shon 등(30)은 노란콩, 대립검정콩 및 소립검정콩을 이용한 청국장의 isoflavone함량이 각각 $499.15,1,278.04$ 그리고 $907.85 \mathrm{\mu g} / \mathrm{g}$ 이며 대립검은콩이 노 란콩에 비해 isoflavone함량이 높다고 보고하였다. Kim 등 (31)은 대풍콩을 이용하여 만든 청국장이 남풍, 소담 및 청자를 이용하여 제조한 청국장에 비해 isoflavone함량이 높다고 보고하였다. 최근 Hwang 등(5)은 대립검정콩(서리 태)를 이용한 청국장이 소립검정콩(서목태)를 이용한 청국 장에 비해 isoflavone 함량이 높다고 보고하였다. 이들의 결과로부터 isoflaovne 유도체 종류와 함량은 가열처리, 콩 품종, 발효기간 및 미생물에 따라 다양한 결과를 나타내기
때문이다.

발효 중 항산화 활성 변화

본 연구에서는 DPPH 라디칼 소거 활성, ABTS 라디칼 소거 활성 및 FRAP assay의 3 가지 방법으로 여주 첨가 청국장 발효 중 항산화 활성을 측정하였다. 전체적으로 여 주 첨가량이 증가 및 발효가 진행됨에 따라 항산화 활성을 증가하는 경향을 나타내었다(Fig. 4).

수소 공여능 검사를 위해서 우리는 DPPH 라디칼 소거 활성을 수행하였다. DPPH 라디칼 소거활성은 발효 $0 \mathrm{hr}$ 째 각각 $30.58 \%$ (여주 무첨가), $42.43 \%$ (여주 $1 \%$ 첨가), $53.78 \%$ (여주 $2.5 \%$ 첨가) 및 $64.07 \%$ (여주 5\% 첨가)에서 발효가 진행됨에 따라 증가하여 발효 $72 \mathrm{hr}$ 째 각각 $70.01 \%, 86.42 \%$, $88.42 \%$ 및 $90.74 \%$ 나타내었다(Fig. 4A). 수소공여항산화와 chain-breaking 활성을 확인하기 위해서 ABTS 라디칼 활성 을 측정하였다. ABTS 라디칼 소거활성은 각각 $60.64 \%$, $65.79 \%, 67.04 \%$ 및 $71.07 \%$ 에서 발효 종기 $(72 \mathrm{hr})$ 각각 $95.69 \%, 95.97 \%, 99.28 \%$ 및 99.79\%로 증가하였다(Fig. 4B). 한편 FRAP assay를 통하여 환원력을 측정하였다. 환원력 역시 라디칼 소거 활성과 동일한 경향을 보여 발효 초기(0 $\mathrm{hr}$ ) 각각 $0.950,0.966,0.980$ 및 1.100 에서 발효 중 지속적으 로 증가하여 최종적으로 $1.250,1.307,1,605$ 및 1.705 로 나타 
났다(Fig. 4C).

총 phenolics 함량은 일반적으로 항산화 활성의 정의 상 관관계를 나타낸다. Shon 등(32)은 청국장 메탄올 추출물은 69 87\% 라디칼 소거활성을 나타내며 총 phenolics 함량은 $0.13 \mathrm{mg} / \mathrm{g} \sim 0.27 \mathrm{mg} / \mathrm{g}$ 로 보고하였다. 반면 Kao 및 Chen(33) 은 DPPH라디칼 소거 활성은 다양한 isoflavone에 영향을 받지 않으며 2 4개의 isoflavone의 혼합물이 DPPH 라디칼 소거 활성에 영향을 미치는 것으로 보고하였다. 이와 유사 하게 많은 isoflavone은 DPPH 자유 라디칼에 대해 낮은 소거능을 가지고 있으며 a-tocopherol 및 epicatechin 유도체 의 절반 정도의 소거능을 가진다고 보고되었다(34). 그러나 isoflavone은 직접적인 자유 라디칼 소거능을 가지며 이 중 특히 dadzein과 genistein이 효과적인 것으로 보고되어 있다.
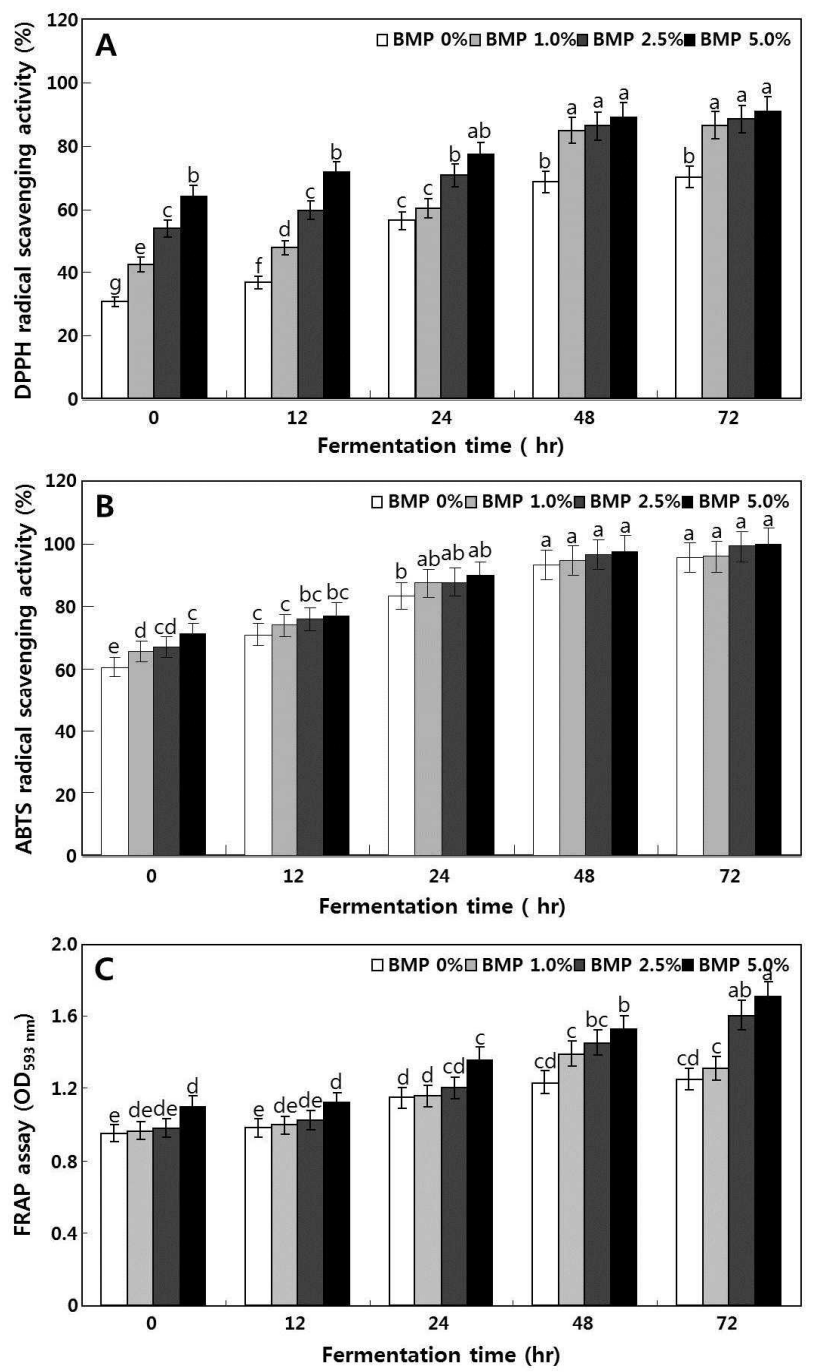

Fig. 4. Changes in the antioxidant activities during the fermentation of Cheonggukjang without and with BMP using B. subtilis CSY191.

A, DPPH radical activity; B, ABTS radical activity; and C, FRAP assay. All values are means of determinations in three independent experiments. Means with different lowercase letters $(a, b, c, d$, and e) indicate significant $(p<0.05)$ differences of fermentation times by Tukey's multiple range test.
더욱이 Kim 등(35)은 청국장 추출물과 이들의 구성 성분 인 daidzein과 genistein은 실험실내에서 중요한 항산화 활성 을 나타낸다고 보고하였다. 또한 몇몇 연구자들에 의해 청 국장 발효 중 항산화 활성은 증가는 총 phenolics 및 isoflavone-aglycones 함량이 증가한 결과로 추정하였다 ((1-2,5,20,22,36). 특히 최근에 $\mathrm{Kim}$ 등(2)은 마늘 첨가 청국 장 발효 중 항산화 활성 증가는 총 phenolics, isoflavoneaglycones, -malonylglycosides 함량 증가와 관련된다고 보 고하였다.

\section{청국장의 관능평가}

일반 청국장(여주 무첨가) 및 여주 첨가 청국장에 대해서 외관, 이취, 향, 맛 및 전체적인 기호도를 조사한 결과 Table 3 과 같았다. 청국장의 외관은 일반 청국장보다 여주 첨가 청국장이 낮은 점수를 획득하였으나, 맛, 향 및 전체적인 기호도에서는 일반 청국장보다 여주 첨가 청국장이 높은 점수를 획득하였다. 특히, 이취에서는 일반 청국장보다 여 주 첨가량이 증가할수록 청국장 특유의 이취도는 낮아지는 것으로 평가되었고 여주 첨가 $2.5 \%$ 청국장이 대체적으로 높은 평가를 받았다.

Park 및 $\mathrm{Cho}(4)$ 는 일반 청국장보다 녹차 $5 \%$ 첨가 청국장 이 항산화 활성 높을 뿐만 아니라 이취에서는 약하다고 보고하였으며, 이는 청국장의 이취와 관계된 암모니아태 질소의 함량이 낮은 것으로 추측하였다. 또한 Park 등(11)은 재래 청국장, 일반 청국장 및 율무 청국장의 이취를 평가한 결과 이취 정도는 율무 청국장이 가장 낮았고 재래 청국장 이 가장 높은 것으로 보고하였다.

본 연구에서는 여주 첨가 정도에 따라 청국장의 발효 중 총 phenolics와 isoflavones 함량 및 항산화 활성 변화를 조사하였고 부가적으로 제조된 청국장에 대해서 관능평가 를 실시하였다. 발효 중 $\beta$-glucosidase 활성 증가함에 따라 총 phenolics와 isoflavone-aglycones 함량은 증가하였고 이 에 상응하여 항산화 활성 역시 증가하였으나, isoflavoneglycosides 함량은 감소하였다. 한편 일반 청국장(여주 무첨

Table 3. Comparison of sensory evaluation of Cheonggukjang without and with BMP

\begin{tabular}{lcccc}
\hline \multirow{2}{*}{ Contents $^{2)}$} & \multicolumn{4}{c}{ Cheonggukjang with BMP (\%) } \\
\cline { 2 - 5 } & 0 & 1.0 & 2.5 & 5.0 \\
\hline Appearance & $3.25 \pm 0.04^{\mathrm{a}}$ & $3.21 \pm 0.03^{\mathrm{a}}$ & $2.98 \pm 0.05^{\mathrm{b}}$ & $2.94 \pm 0.02^{\mathrm{b}}$ \\
Off-odor & $4.33 \pm 0.05^{\mathrm{a}}$ & $4.28 \pm 0.04^{\mathrm{a}}$ & $4.01 \pm 0.04^{\mathrm{ab}}$ & $3.88 \pm 0.02^{\mathrm{b}}$ \\
Overall flavor & $3.98 \pm 0.06^{\mathrm{b}}$ & $4.08 \pm 0.04^{\mathrm{b}}$ & $4.32 \pm 0.03^{\mathrm{a}}$ & $4.41 \pm 0.03^{\mathrm{a}}$ \\
Overall taste & $3.78 \pm 0.01^{\mathrm{b}}$ & $3.84 \pm 0.03^{\mathrm{b}}$ & $4.08 \pm 0.03^{\mathrm{a}}$ & $4.02 \pm 0.04^{\mathrm{a}}$ \\
Overall acceptability & $3.85 \pm 0.04^{\mathrm{a}}$ & $3.84 \pm 0.05^{\mathrm{a}}$ & $3.99 \pm 0.03^{\mathrm{a}}$ & $3.87 \pm 0.02^{\mathrm{a}}$ \\
\hline
\end{tabular}

${ }^{1)}$ Cheonggukjang fermented without BMP and with $1-5 \%$ (w/w) of BMP.

${ }^{2)}$ All values are means of determinations in thirty independent experiments. Means with different lowercase letters $(a$ and $b)$ indicate significant $(p<0.05)$ differences of fermentation times by Tukey's multiple range test. 
가)보다 여주 첨가 청국장이 청국장 특유의 이취가 낮은 것으로 평가되었다. 이 결과로부터 여주 첨가를 통한 기능 성과 이취 저감형 청국장 제조가 가능할 것으로 판단되었 다.

\section{요 약}

본 연구에서는 여주 분말(bitter melon powder, BMP) 첨 가 청국장 발효 중 $\beta$-glucosidase 활성 변화, 총 phenolics와 isoflavone 함량, 항산화 활성 변화 및 관능평가를 조사하였 다. 청국장 발효 중 $\beta$-glucosidase 활성은 $48 \mathrm{hr}$ 까지는 증가 한 후 $72 \mathrm{hr}$ 에는 감소하였으며, 총 phenolics, isoflavonemalonylglycoside 및 isoflavone-aglycone 함량은 증가하였 고 이에 상응하여 항산화 활성 역시 증가하였으나, 총 isoflavone 및 isoflavone-glycoside 함량은 감소하였다. 한편, 발효종기 $5 \% \mathrm{BMP}$ 첨가 청국장은 또 다른 시료들과 비교하 여 가장 높은 항산화 활성을 나타내었다. 특히, 발효 72 $\mathrm{hr}$ 후 $5 \% \mathrm{BMP}$ 첨가 청국장의 총 phenolics와 daidzein 함량 및 $\mathrm{DPPH}$ 라디칼 소거 활성, ABTS 라디칼 소거 활성 및 환원력은 각각 $13.5 \mathrm{mg} / \mathrm{g}, 390.57 \mathrm{\mu g} / \mathrm{g}, 90.74 \%, 99.79 \%$ 및 $1.705\left(\mathrm{OD}_{593} \mathrm{~mm}\right)$ 있었다. 부가적으로 여주 분말이 첨가될수 록 청국장의 이취도는 감소하였다. 이들 결과로부터 여주 분말 첨가로 기호성과 항산화 활성이 개선된 새로운 타입의 청국장 제조가 가능할 것으로 판단되었다.

\section{감사의 글}

이 논문은 2013년 국립경남과학기술대학교의 기성회 연 구비에 의하여 연구되었습니다.

\section{References}

1. Shin EC, Lee JH, Hwang CE, Lee BW, Kim HT, Ko JM, Baek IY, Shin JH, Nam SH, Seo WT, Cho KM (2014) Enhancement of total phenolic and isoflavoneaglycone contents and antioxidant activities during Cheonggukjang fermenation of brown soybeans by the potential probiotic Bacillus subtilis CSY191. Food Sci Biotechnol, 23, 531-538

2. Kim JH, Hwang CE, Lee CK, Lee JH, Kim GM, Jeong SH, Shin JH, Kim JS, Cho KM (2014) Characteristics and antioxidant effect of garlic in the fermentation of Cheonggukjang by Bacillus amyloliquefaciens MJ1-4. J Microbiol Biotechnol, 24, 959-968
3. Lee JH, Lee BW, Kim B, Kim HT, Ko JM, Baek IY, Seo WT, Kang YM, Cho KM (2013) Changes in phenolic compounds (isoflavones and phenolic acids) and antioxidant properties in high-protein soybean (Glycine $\max$ L., cv. Saedanbaek) for different roasting conditions. J Korean Soc Appl Biol Chem, 56, 605-612

4. Park HY, Cho EJ (2008) Radical scavenging effects and physicochemical properties of seolitae Chungkukjang added with green tea. J Korean Soc Food Sci Nutr, 37, 401-404

5. Hwang CE, Seo WT, Cho KM (2013) Enhanced antioxidant effect of black soybean by Cheonggukjang with potential probiotic Bacillus subtilis CSY191. Korean J Microbiol, 49, 391-397

6. Choi EJ, Lee JS, Chang JS, Chang HB, Lee MS, Jang HD, Kwon YI (2010) Changes in the functionality of Cheonggukjang during fermentation supplement with Angelica gigas, Rehmanniae radix, and red ginseng. Korean J Microbiol Biotechnol, 38, 467-474

7. Hong SC, Kwon DJ (2011) Changes in quality characteristics of Cheonggukjang added with deodeok. Korean J Food Preserv, 18, 171-177

8. Kim JH, Park LY, Lee SH (2012) Fermentation and quality characteristics of Cheonggukjang with Chinese cabbage. Korean J Food Preserv, 19, 659-664

9. Jeong TS, Kim JH, An SA, Won YD, Lee SH (2013) Effect of black garlic on antioxidant activity and amino acids composition in Cheonggukjang. Korean J Food Preserv, 20, 643-649

10. Lee MY, Chang KH (2010) Quality properties and isoflavone contents of Chungkukjang containing isoflavone extracted from arrowroot (Pueraria lobata ohwi). J East Asian Soc Dietary Life, 20, 543-550

11. Park JH, Han CK, Choi SH, Lee BH, Lee HJ, Kim SS (2011) Development of odor-reduced Korean traditional Cheonggukjang added with Job's tears. J Korean Soc Food Sci Nutr, 40, 259-266

12. Kim US, Kim JY, Kim SJ, Moon KH, Baek SH (2012) Isoflavonoid contents, antibacterial activities, and physiological activities of Cheonggukjang made from sword bean. J Korean Soc Food Sci Nutr, 41, 174-181

13. Kim AK, Lee HJ, Oh MM, Lee WM, Lee SG, Chae WB, Choi HS, Yang EY, Huh YC, Park DK, Kim S (2013) Selection of bitter gourd (Momordica charantia L.) germplasm for improvement anti-diabetic compound contents. Korean J Breed Sci, 45, 332-338

14. Boo HO, Lee HH, Lee JW, Hwang SJ, Park SU (2009) 
Different of total phenolics and flavonoids, radical scavenging activities and nitrite scavenging effects of Momordica charantia L. according to cultivars. Korean J Medicinal Crop Sci, 17, 15-20

15. Park Y, Boo HO, Park YL, Cho DH, Lee HH (2007) Antioxidant activity of Momordica charantia L. extracts. Korean J Medicinal Crop Sci, 15, 56-61

16. Choi JR, Choi JM, Lee SH, Cho KM, Cho EJ, Kim HY (2014) The protective effects of protocatechuic acid from Momordica charantia against oxidative stress in neuronal cells. Korean J Pharmacogn, 45, 11-16

17. Lee HH, Cheong MJ, Song SY, Boo HO (2009) Effects of Momordica charantia L. water extracts on the rat liver and kidney with acute toxicated by lead. Korean J Microscopy, 39, 355-363

18. Lee HJ, Moon JH, Lee WM, Lee SG, Kim AK, Woo YH, Park DK (2012) Charantin contents and fruit characteristics of bitter gourd (Momordica charantia L.) accessions. J Bio-Environ Cont, 21, 379-384

19. Lee JH, Nam SH, Seo WT, Yun HD, Hong SY, Kim MK, Cho KM (2012) The production of surfactin during the fermentation of Cheonggukjang by potential probiotic Bacillus subtilis CSY191 and the resultant growth suppression of MCF-7 human breast cancer cells. Food Chem, 131, 1347-1354

20. Cho KM, Lee JH, Yun HD, Ahn BY, Kim H, Seo WT (2011) Changes of phytochemical constituents (isoflavones, flavanols, and phenolic acids) during Cheonggukjang soybeans fermentation using potential probiotics Bacillus subtilis CS90. J Food Comp Anal, 24, 402-410

21. Folin O, Denis W (1912) On phosphotungsticphosphomolybdic compounds as color reagents. J Biol Chem, 12, 239-243

22. Cho KM, Hong SY, Math RK, Lee JH, Kambiranda DM, Kim JM, Md. Islam SA, Yun MG, Cho JJ, Lim WJ, Yun HD (2009) Biotransformation of phenolics (isoflavones, flavanols and phenolic acids) during the fermentation of Cheonggukjang by Bacillus pumilus HY1. Food Chem, 114, 413-419

23. Choi JS, Kim HY, Seo WT, Lee JH, Cho KM (2012) Roasting enhances antioxidant effect of bitter melon (Momordica charantia L.) increasing in flavan-3-ol and phenolic acid contents. Food Sci Biotechnol, 21, 19-26

24. Cho KM, Joo OS (2014) Quality and antioxidant charactistics of Elaeagnus multiflora wine through the thermal processing of juice. Korean J Food Preserv, 206-214

25. Kim HG, Kim GW, Oh H, Yoo SY, Kim YO, Oh MS (2011) Influence of roasting on the antioxidant activity of small black soybean (Glycine max L. Merrill). LWT - Food Sci Technol, 44, 992-998

26. Pratt DE, Birac PM, Porter WL, Giffee JW (1981) Phenolic antioxidants of soy protein hydrolyzates. J Food Sci, 47, 24-25

27. Seo A, Morr CV (1984) Improved high-performance liquid chromatographic analysis of phenolic acids. J Agric Food Chem, 32, 530-533

28. Park HS, Shin SR, Hong JY, Yang KM (2013) Comparison of the antioxidant activities of small-blackbean-Chungkukjang-added black food and soybean Chungkukjang extracts. Korean J Food Preserv, 20, 735-743

29. Yang SO, Chang PS, Lee JH (2006) Isoflavone distribution and $\beta$-glucosidase activity in Cheonggukjang, a traditional Korean whole soybean-fermented food. Food Sci Biotechnol, 15, 96-101

30. Shon MY, Seo KI, Lee SW, Choi SH, Sung NJ (2000) Biological activities of Cheonggukjang prepared with black bean and changes in phytoestrogen content during fermentation. Korean J Food Sci Technol, 32, 936-941

31. Kim MH, Kim SY, Ko JM, Jeong DY, Kim YS (2012) Biological activities of Cheonggukjang prepared with several soybean cultivars. Food Sci Biotechnol, 21, 475-483

32. Shon MY, Lee J, Choi SY, Nam SH, Seo KI, Lee SW, Sung NJ, Park SK (2007) Antioxidant and free radical scavenging activity of methanol extract of Chungkukjang. J Food Comp Anal, 20, 113-118

33. Kao TH, Chen BH (2006) Functional components in soybean cake and their effects on antioxidant activity. J Agric Food Chem, 54, 7544-7555.

34. Lee CH, Yang L, Xu JZ, Yeung SYV, Huang Y, Chen Z-Y (2005) Relative antioxidant activity of soybean isoflavones and their glycosides. Food Chem, 90, 735-741

35. Kim NY, Song EJ, Kwon DY, Kim HP, Heo MY (2008) Antioxidant and antigenotoxic activities of Korean fermented soybean. Food Chem Toxicol, 46, 1184-1189

36. Kwak CS, Lee MS, Park SC (2007) Higher antioxidant of Chungkookjang, a fermented soybean paste, may be due to increased aglycone and malonylgycoside isoflavone during fermentation. Nutr Res, 27, 719-727 